\title{
SINERGITAS TIGA PILAR \\ PENJAMIN MUTU PENDIDIKAN \\ DALAM IMPLEMENTASI KURIKULUM 2013 MELALUI PROSES \\ SUPERVISI AKADEMIK PADA MADRASAH ALIYAH SEKOTA METRO
}

\author{
Aguswan Khotibul Umam \\ IAIN Metro Lampung \\ Email: Kaguswan@yahoo,co.id
}

\begin{abstract}
This research is intended to describe critically and qualitatively the synergy among Islamic education supervisor, head master, and Islamic education teacher in implementing 2013 curriculum through academic supervision. The data collecting techniques used in this research are observation, interview, and document review. The results of the research are (1) the supervision is conducted by Islamic education supervisor not only gradually but also incidentally through academic, administrative, and clinical supervision; (2) the academic supervision of Islamic education at MA Metro city is conducted based on qualified Islamic education supervisor, eight education quality standards, prime duty and function of Islamic education supervisor, effective madrasah management by head master, vision, mission and Islamic education strategy, and terms of reference of Islamic education supervision; 3) there are several problems that supervisor, head master, and Islamic education teacher have in implementing 2013 curriculum; 4) the synergy of quality assurance in implementing K13 must be based on maximum effort of Islamic education supervisor, head master, and Islamic education teachers at MA that are conducted according to eight terms of reference: inspecting, advising, monitoring, reporting, coordinating, and performing leadership.
\end{abstract}

Keywords: Synergy, quality assurance in education, academic supervision, implementation, 2013 curriculum.

\section{Abstrak}

Penelitian ini bertujuan untuk mendeskripsikan secara kritis kualitatif tentang sinergitas pengawas PAI, kepala madrasah dan para guru PAI dalam implementasi kurikulum 2013 melalui supervisi akademik. Teknik pengumpulan datanya yaitu observasi, wawancara dan dokumentasi. Hasil penelitianya yaitu: (1) Kegiatan kepengawasan dilaksanakan secara rutin dan incidental oleh pengawas PAI melalui supervisi akademik, supervisi administrasi dan supervisi klinis, (2). Supervisi akademik PAI MA Kota Metro dikoordinatori oleh Pengawas PAI dengan memperhatikan aspek kualifikasi Pengawas PAI, Delapan Standar Mutu Pendidikan, Tugas dan Fungsi Pokok Pengawas, Pengelolaan Madrasah Efektif oleh Kepala MA, Visi, Misi dan Strategi Pengawasan PAI, Srategi dan lingkup Pengawasan, (3) Terdapat problema implementasi kurikulum 2013 yang terdapat pada pengawas, para Kepala MA dan para guru PAI, (3) Pelaksanaan sinergitas penjaminan mutu dalam implementasi K13 dilakukan melalui upaya maksimal Pengawas PAI, Kepala MA dan para guru PAI MA melalui suksesi pada kepengawasan penyelenggaraan PAI, tatakelola madrasah, tugas kepala MA dan GPAI MA, dan pelaksanaan ekstra kurikuler PAI. Secara operasionalisasinya tugas-tugas 
kepengawasan tersebut dirinci dengan enam cakupan tugas pengawas yaitu Inspection, Advising, Monitoring, Reporting, Coordinating dan Performing Leadership.

Kata Kunci: Sinergitas, Penjamin mutu pendidikan, supervisi akademik, Implementasi, Kurikulum 2013

\section{A. Pendahuluan}

Pengawas PAI, kepala madrasah, dan guru merupakan tiga pilar penjamin mutu madrasah yang berperan penting dalam mewujudkan implementasi Kurikulum 2013 pada madrasah di bawah Kementerian Agama RI. Efektivitasnya bergantung pada kesesuaian kompetensi serta sinergitas ketiganya dalam mewujudkan target yang diharapkan pada tingkat satuan pendidikan. Peningkatan kompetensi dan sinergitasnya dilakukan melalui berbagai cara yaitu sosialisasi, pelatihan, workshop, dan penyamaan persepsi, misi, visi serta implementasi dari K 2013.

Para pengawas PAI dan kepala madrasah bertugas melaksanakan supervisi akademik kepada para guru secara efektif, dengan karakteristik yaitu: 1) Kemampuan mengembangkan kompetensi pengawas PAI untuk memahami K 2013 dan mentransformasikannya; 2), kemampuan menunjukkan sikap keberterimaan, pengetahuan, dan keterampilan serta daya inisiatif yang tinggi untuk merencanakan strategi dan implementasi perencanaan, pelaksanaan, dan evaluasi pengawasan dan pembinaan madrasah sesuai kebutuhan khas implementasi $\mathrm{K}$ 2013; 3), kemampuan meminimalisir resistensi pada implementasi K2013 pada tingkat satuan pendidikan; 4), kemampuan berkontribusi positif bagi tenaga pendidik dan tenaga kependidikan di madrasah melalui sikap, pengetahuan dan keterampilan serta kompetensi pada pengawas PAI; 5), kemampuan menyelaraskan seluruh kompetensi yang dikembangkan untuk menunjang penjaminan mutu kompetensi lulusan, isi, proses pembelajaran, dan penilaian sesuai dengan karakteristik kurikulum 2013.1

Proses supervisi kurikulum 2013 dimaksudkan untuk penyamaan persepsi tentang pemahaman, pemeliharaan, dan peningkatan kualitas implementasi K 2013 serta mengatasi problematikanya, yaitu: (a) Guru belum siap dan sulit mengubah pola pikirnya; (b) Guru pada beberapa mata pelajaran kehilangan tugas dan jam mengajar; dan (c) Isi buku tidak sesuai. ${ }^{2}$

\footnotetext{
1 Pusat Pengembangan Tenaga Kependidikan, Supervisi Akademik Implementasi Kurikulum 2013, (Jakarta: Kemendikbud, 2014), h. ii

2 Farida Alawiyah, “Dampak Implementasi Kurikulum 2013 terhadap Guru” dalam INFO SINGKAT (Jakarta: Pengkajian, Pengolahan Data dan Informasi (P3DI) Sekretariat Jenderal DPR RI), Vol. V, No. 19/I/P3DI/Oktober/2013. h. 11. 1; bahwa: (a). Guru belum siap mengubah pola pikirnya, maka perlu dilakukan penyiapan guru dilakukan melalui pelatihan yang telah diprogramkan pemerintah secara hierarki mulai dari pemilihan instruktur nasional, guru inti, guru kelas, dan guru mata pelajaran. Para guru kelas maupun guru mata pelajaran tetap dalam pengawasan serta pendampingan. (b). Guru pada beberapa mata pelajaran kehilangan tugas dan jam mengajar. Meniadakan dan menggabungkan beberapa mata pelajaran menjadi keresahan tersendiri untuk guru. (c). Isi buku tidak sesuai. Peserta didik dan guru diberikan buku yang telah disusun oleh pusat, namun, ditemukan adanya ketidaksesuaian antara isi buku dengan materi dan perkembangan kognitif peserta didik.
} 
Beberapa keluhan guru pada implementasi K 2013 yaitu:3 1), salah satu pembeda K 2013 dengan kurikulum sebelumnya ialah scientific approach, namun banyak guru yang merasa kesulitan menerapkannya, Terdapat banyak hal yang belum dipahami guru terkait K 2013, sistem penilaian yang dianggap rumit, 2), Dari lima langkah pendekatan scientific, yakni mengamati, menanya, menalar, mencoba, dan membentuk jejaring, yang sering terlewat ialah menalar, 3). Kesulitan guru untuk membuat siswa aktif, guru harus pintar menjadi fasilitator agar siswa bertanya dan berdiskusi. Persoalan lainnya ialah terkait project based learning dan pelatihan guru yang belum maksimal dan merata.

Demikian pula dengan hasil angket ${ }^{4}$ tentang kesulitan guru dalam penerapan K 2013 menunjukkan bahwa sebanyak 20 dari 23 guru SMP 21 Semarang yang mengisi angket, diperoleh hasil yaitu " 87 persen (20 dari 23 guru) mengalami kesulitan dalam memahami cara penilaian, 70 persen (16 dari 23 guru) kesulitan dalam pembuatan instrumen observasi, 66 persen (15 dari 23 guru) kesulitan dalam memahami model-model pembelajaran, dan 79 persen (18 dari 23 guru) mengalami kesulitan membuat instrumen penilaian. Hal ini artinya guru di memang sangat membutuhkan supervisi akademik oleh para supervisor pendidikan mereka.

Tugas pengawas PAI pada implementasi K 2013 yaitu: 1) Melakukan supervisi dan fasilitasi keterlaksanaan pengelolaan K 2013 yang dilakukan kepala madrasah, dan 2) Melakukan supervisi dan fasilitasi keterlaksanaan perencanaan model pembelajaran. Para pengawas PAI bertugas pula memotivasi para Kepala Madrasah untuk menerapkan konsep dan strategi kepemimpinan pembelajaran yang relevan dengan implementasi K 2013, yaitu: “Keteladanan, pembelajaran di kelas dan di luar kelas, kultur sekolah, dan penguatan. Keteladanan adalah ucapan, bahasa tubuh, sikap, dan tindakan positif yang dapat dicontoh oleh orang lain. Pembelajaran adalah kegiatan eksplorasi, elaborasi, dan konfirmasi untuk mentransformasikan, melestarikan, dan mengkritisi iptek dan kultur yang dilakukan di dalam dan di luar kelas. Kultur sekolah adalah keyakinan-keyakinan, nilai-nilai, norma-norma, tradisi bersama yang mengikat kebersamaan seluruh warga sekolah". 5

Pengawas PAI bertugas pula mendukung keberhasilan guru PAI dalam tugas mereka, yaitu pada aspek memenuhi tuntutan realitas tugas guru PAI yaitu: "Untuk memiliki high responsibility, inovasi \& kreasi khususnya dalam mencipta pembelajarannya. GPAI sebagai desainer pembelajaran, yaitu harus mampu mengeksplor berbagai sumber belajar di sekitar

\footnotetext{
3 TP.Tiga Masalah Guru dalam Implementasi Kurikulum 2013. Dalam http://news.okezone.com/read/2014/10/16/65/1052959/tiga-masalah-guru-dalam-implementasi-kurikulum-2013, diunduh tanggal, 2 April 2016.

4 Ani Rusilowati, Kurikulum 2013, 87 Persen Guru Kesulitan Cara Penilaian, dalam http://unnes.ac.id/berita/87-persen-guru-kesulitan-soal-penilaian-kurikulum-2013/, diunduh pada tanggal 12 November 2014. Data tersebut adalah Angket yang dibagikan oleh Prof Ani Rusilowati MPd Professor Fakultas Matematika dan Ilmu Pengetahuan Alam (FMIPA) Universitas Negeri Semarang (Unnes), kepada sebanyak 20 dari 23 guru SMP 21 Semarang.

${ }^{5}$ Husaini Usman dan Nuryadin Eko Raharjo. "Strategi Kepemimpinan Pembelajaran Menyongsong Implementasi Kurikulum 2013” dalam Cakrawala Pendidikan, Februari 2013, Th. XXXII, No. 1, h. 11-12.
} 
untuk selanjutnya menjadikannya sebagai media pembelajaran bagi peserta didik. Dengan demikian GPAI benar-benar dituntut proaktif - bukan pasif." ${ }^{6}$

Secara umum para Pengawas PAI bertugas untuk melaksanakan supervisi akademik pada implementasi kurikulum 2013 dengan tiga fungsi: 1. Pembinaan kurikulum untuk menjamin penyampaian kurikulum dengan tepat; 2. Perbaikan proses pembelajaran dengan membantu guru merencanakan program akademis, dan 3. Pengembangan profesi dalam melaksanakan program pengajaran. ${ }^{7}$

Pada konteks implementasi K 2013 pada madrasah di Kota Metro, diperoleh informasi bahwa proses implementasi K 2013 untuk mata pelajaran rumpun PAI (Aqidah Akhlak, Fiqih, dan Sejarah Kebudayaan Islam) di seluruh madrasah di Kota Metro Lampung telah mulai dilaksanakan..Pelaksanaan ini dilakukan didasarkan pada siapnya tiga pilar penjamin mutu pendidikan madrasah yang ada yaitu para pengawas PAI, kepala madrasah dan para guru PAI.

Personal yang telah mengikuti program Diklat implementasi K 2013 yaitu Kasi Mapenda dan Ketua Kelompok Kerja Pengawas (Pokjawas) dan Para Pengawas PAI, kepalakepala madrasah dan guru inti. Guru inti yang telah mengikuti Diklat implementasi K 2013 yaitu terdiri atas 18 orang guru inti tingkat MI, 3 orang guru inti tingkat MTs dan 6 orang guru inti tingkat MA. Telah dilaksanakan pula kegiatan diklat implementasi K 2013 bagi 40 guru dari utusan MIN, MIS, MTs, MAN dan MAS sekota Metro pada tanggal 29 Maret $2014 .^{8}$

Para pengawas PAI Kota Metro telah selalu rutin mensosialisasikan dan menelaah bersama terkait hal-hal K 2013 di wilayah kerja Kemenag Kota Metro, dan diikuti dengan program supervisi administrasi, akademik dan klinis kepada seluruh madrasah di Kota Metro. ${ }_{9}$ Demikian pula pada level MA, supervisi terhadap para guru rumpun PAI di MA Kota Metro dilaksanakan secara rutin, secara triwulan maupun secara insidental. Terdapat 8 MA di Kota Metro yaitu 1) MA Negeri 2 Metro, 2). MA Da'rul Akmal, 3). MA Tuma'ninah Yasin, 4). MA Khusnul Khotimah, 5). MA Roudhotul Tholibin, 6). MA Al Mukhsin, 7). MA Muhammadiyah dan 8). MA Mambaul Ulum, Pengawas PAI melakukan supervisi secara menyeluruh, dan melakukan kunjungan pada acara-acara tertentu terkait kegiatan akademis seperti rapat awal tahun ajaran baru, persiapan akreditasi dan kunjungan mendadak lainnya.

Para kepala MA berkewajiban mensupervisi internal kepada para guru dan tenaga kependidikan yang ada dan para Guru PAI harus berupaya meningkatkan profesionalitas masing-masing, sesuai dengan tindak lanjut dari hasil supervisi. Pada aspek ini, para guru PAI MA di Kota Metro belum memiliki wadah koordinasi seperti MGMP (Musyawarah Guru Mata Pelajaran) sebagai sarana diskusi antara pengawas PAI, kepala MA dan para guru PAI yang ada. Kondisi ini menjadi salah satu aspek kurangnya aspek persamaan persepsi dan kerjasama antar guru PAI MA di Kota Metro dalam impelementasi K 2013. Berdasarkan latar belakang di atas dan posisi strategis pada peran pengawas PAI dalam proses implementasi K 2013, yang

6 Trianto, “Mempersiapkan Guru PAI dalam Mengimplementasikan Kurikulum 2013”, dalam EDUKASIA, MPA 320/Mei 2013, h. 37.

7 Departemen Agama RI, Model-Model Pelatihan bagi Pengawas Sekolah, (Jakarta: Departemen Agama, 2005), h. 86.

${ }^{8}$ Wawancara dengan Dra. Nuryanah, MM, Kasi Mapenda Kemenag Kota Metro, 1 April 2016.

${ }_{9}^{9}$ Wawancara dengan Ketua Pokja Pengawas PAI Kemenag Kota Metro, 1 April 2016. 
bersinergi dengan para kepala MA dan para guru PAI di Kota Metro maka penelitian yang bersifat kualitatif ini menjadi relevan.

Rumusan permasalahan yaitu: 1).Bagaimanakah identifikasi hasil kepegawasan dan kebijakan dalam bidang pendidikan dalam kepengawasan PAI Madrasah Aliyah di Kota Metro?, 2). Bagaimanakah pola penjaminan mutu pendidikan dalam implementasi Kurikulum K13 melalui pengawasan akademik pada guru rumpun PAI pada Madrasah Aliyah di Kota Metro?, 3). Bagaimanakan problematika penjaminan mutu pendidikan dalam implementasi Kurikulum K13 melalui pengawasan akademik pada guru rumpun PAI pada Madrasah Aliyah di Kota Metro?, dan 5). Bagaimanakah pelaksanaan sinergitas penjaminan mutu pendidikan dalam implementasi Kurikulum K13 melalui pengawasan akademik pada guru rumpun PAI pada Madrasah Aliyah di Kota Metro?.

\section{B. Kajian Pustaka}

\section{Pengembangan Kurikulum 2013 pada Madrasah}

Madrasah sebagai sekolah yang bercirikan agama Islam dalam pengembangan kurikulumnya tidak terlepas dari kebijakan pemerintah terkait perubahan dan perkembangan kurikulum secara nasional termasuk dengan kurikulum 2013. Para stakeholder di madrasah harus memahami akan titik tekan dari pengembangan Kurikulum 2013 adalah penyempurnaan pola pikir, penguatan tata kelola kurikulum, pendalaman dan perluasan materi, penguatan proses pembelajaran, dan penyesuaian beban belajar agar dapat menjamin kesesuaian antara hal yang diinginkan dengan hal yang dihasilkan, serta memahami prinsip utama dari pengembangan $\mathrm{K} 2013$.

Pengembangan K 2103 tersebut yaitu: Pertama, standar kompetensi lulusan diturunkan dari kebutuhan. Kedua, standar isi diturunkan dari standar kompetensi lulusan melalui kompetensi inti yang bebas mata pelajaran. Ketiga, semua mata pelajaran harus berkontribusi terhadap pembentukan sikap, keterampilan, dan pengetahuan peserta didik. Keempat, mata pelajaran diturunkan dari kompetensi yang ingin dicapai. Kelima, semua mata pelajaran diikat oleh kompetensi inti. Keenam, keselarasan tuntutan kompetensi lulusan, isi, proses pembelajaran, dan penilaian. Aplikasi yang taat asas dari prinsip-prinsip ini menjadi sangat esensial dalam mewujudkan keberhasilan implementasi Kurikulum 2013.10

Para stakeholder madrasah harus memahami pula akan orientasi K 2013 adalah terjadinya peningkatan dan keseimbangan antara kompetensi sikap (attitude), keterampilan (skill) dan pengetahuan (knowledge) pada siswa madrasah. Hal ini sejalan dengan amanat UU Nomor 20 Tahun 2003 tentang Sistem Pendidikan Nasional, dalam Penjelasan Pasal 35 yang menyatakan, bahwa kompetensi lulusan merupakan kualifikasi kemampuan lulusan yang mencakup sikap, pengetahuan, dan keterampilan sesuai dengan standar nasional yang telah disepakati.

Hal-hal yang penting dipahami dalam pengembangan Kurikulum 2013 adalah, 1). Perubahan proses pembelajaran dari peserta didik diberi tahu menjadi peserta didik mencari tahu dan proses penilaian dari berbasis output menjadi berbasis proses dan output]

${ }_{10}$ Kementerian Agama RI, Modul Pelatihan Implementasi Kurikulum 2013 bagi Guru, (Jakarta: Direktorat Jenderal Pendidikan Islam Direktorat Pendidikan Agama Islam Kementerian Agama, 2013), h. iii. 
memerlukan penambahan jam pelajaran; 2). Kecenderungan akhir-akhir ini banyak negara menambah jam pelajaran KIPP dan MELT di AS, Korea Selatan; 3). Perbandingan dengan negara-negara lain menunjukkan jam pelajaran di Indonesia relatif lebih singkat, dan 4). Walaupun pembelajaran di Finlandia relatif singkat, tetapi didukung dengan pembelajaran tutorial. ${ }^{11}$

Pada kurikulum 2006 sebelumnya masih terdapat sejumlah problema, yaitu: 1). Kurikulum belum sepenuhnya berbasis kompetensi sesuai dengan tuntutan fungsi dan tujuan pendidikan nasional; 2). Kompetensi belum menggambarkan secara holistik domain sikap, keterampilan, dan pengetahuan; 3). Beberapa kompetensi yang dibutuhkan sesuai dengan perkembangan kebutuhan (misalnya pendidikan karakter, metodologi pembelajaran aktif, keseimbangan soft skills dan hard skills, kewirausahaan) belum terakomodasi di dalam kurikulum; 4). Kurikulum belum peka dan tanggap terhadap perubahan sosial yang terjadi pada tingkat lokal, nasional, maupun global; 5). Standar proses pembelajaran belum menggambarkan urutan pembelajaran yang rinci sehingga membuka peluang penafsiran yang beraneka ragam dan berujung pada pembelajaran yang berpusat pada guru; 6).Standar penilaian belum mengarahkan pada penilaian berbasis kompetensi (proses dan hasil) dan belum secara tegas menuntut adanya remediasi secara berkala; dan 7). Dengan KTSP memerlukan dokumen kurikulum yang lebih rinci agar tidak menimbulkan multi tafsir. ${ }^{12}$

Permasalahan-permasalahan tersebut hendaknya menjadi perhatian serius oleh semua pihak yang berkompeten dalam suksesi kurikulum 2013 di madrasah. Perubahan kurikulum merupakan hasil penting dari kajian mendalam dari implementasi kurikulum sebelumnya, yaitu dengan melakukan studi dokumentasi dan kajian konsep tentang pengembangan kurikulum dan penerapannya. Kajian ini meliputi konsep dan falsafah dalam sistem pengembangan kurikulum, muatan dan konten kurikulum, perencanaan pembelajaran, pengembangan bahan ajar, sistem pengadministrasian dan pelaksanaan pembelajaran. Sedangkan dokumen tersebut meliputi kurikulum, studi perbandingan antar kurikulum, perencanaan pembelajaran, bahan ajar, pengadministrasian dan pelaksanaan pembelajaran. ${ }^{13}$

Hasil analisis digunakan untuk mendapatkan informasi tentang hambatan, peluang maupun tantangan dari setiap kurikulum yang diterapkan oleh satuan pendidikan. Efektivitas implementasi kurikulum sangat ditentukan oleh praktek pembelajarannya di madrasah. Untuk itu perlu dilakukan diskusi fokus pelaksanaan kegiatan belajar, sumber belajar dan lingkungan pendukungnya di tempat belajar, yang melibatkan berbagai karkateristik setiap satuan pendidikan. Beragamnya kondisi satuan pendidikan sehingga diperlukan data dan informasi komprehensif untuk menjaring data dan informasi perencanaan, praktek pembelajaran dan manajemen pengelolaan pembelajaran oleh satuan pendidikan.

11 Trianto, “Mempersiapkan Guru PAI dalam Mengimplementasikan Kurikulum 2013”, dalam Jurnal Edukasia, MPA 320/Mei 2013, h. 37.

12 Ibid.

13 Departemen Pendidikan Nasional, Laporan Hasil Diskusi Kajian Kurikulum Pendidikan Dasar, (Jakarta: Badan penelitian dan pengembangan Pusat kurikulum, 2008), h.2 


\section{Supervisi Akademik Implementasi Kurikulum 2013 oleh Pengawas PAI}

a. Supervisor PAI sebagai Pendamping Guru

Bidang Pendidikan Agama Islam pada struktur organisasi Kementerian Agama merupakan bidang baru sebagai anomali Bidang Madrasah dan Pendidikan Agama (Mapenda) berekspansi menjadi Bidang Pendidikan Madrasah dan Bidang Pendidikan Agama Islam.

Peraturan Menteri Agama Nomor 13 Tahun 2012 tentang Organisasi dan Tata Kerja Instansi Vertikal Kementerian Agama Pasal 477 menegaskan bahwa Bidang Pendidikan Agama Islam mempunyai tugas melaksanakan pelayanan, bimbingan, pembinaan, dan pengelolaan sistem informasi di bidang pendidikan agama Islam berdasarkan kebijakan teknis yang ditetapkan oleh Kepala Kantor Wilayah Kementerian Agama. Untuk melaksanakan tugas tersebut Bidang Pendidikan Agama Islam menyelenggarakan tujuh buah fungsi yaitu: ${ }^{14}$

Pertama, penyiapan perumusan kebijakan teknis dan perencanaan di bidang pendidikan agama Islam; Kedua, pelaksanaan pelayanan, bimbingan, dan pembinaan di bidang pendidikan agama Islam pada Pendidikan Anak Usia Dini (PAUD), Taman Kanak-kanak (TK), Sekolah Dasar/Sekolah Dasar Luar Biasa (SD/SDLB), Sekolah Menengah Pertama/Sekolah Menegah Pertama Luar Biasa(SMP/SMPLB), Sekolah Menengah Atas/Sekolah Menengah Atas Luar Biasa/Sekolah Menengah Kejuruan (SMA/SMALB/SMK), serta pengelolaan sistem informasi pendidikan agama Islam; Ketiga, melakukan evaluasi dan penyusunan laporan di bidang pendidikan agama Islam.

Bidang PAI merumuskan berbagai rencana program kegiatan, antara lain:

1) Peningkatan kompetensi Guru PAI dengan menyelenggarakan berbagai kegiatan workshop antara lain workshop model pembelajaran inovatif, workshop pengembangan perangkat pembelajaran, workshop pengembangan keprofesian berkelanjutan (PKB) dan PTK, workshop pengembangan penilaian berbasis kelas (PBK), workshop penilaian kinerja guru (PKG), workshop pengembangan media pembelajaran berbasis IT, dan khusus bagi Guru PAI TK/SD dibekali pula dengan Model Pembelajaran Tematik.

2) Pemberdayaan kelompok Guru PAI. Kegiatan ini dilakukan dengan sosialisasi Kurikulum 2013 kepala kelompok Guru PAI seperti FKG PAI TK, KKG PAI SD, dan MGMP PAI SMP/SMPLB/SMA/SMALB dan SMK.

3) Peningkatan akses dan mutu pendidikan agama Islam. Kegiatan ini dilakukan dengan mengawali pendataan Guru PAI dan Kelompok Guru PAI (EMIS) tiap tahun dengan tujuan untuk memperoleh data valid tentang jumlah Guru PAI, jumlah Guru PAI yang sudah/ belum tersertifikasi, jumlah guru PAI yang sudah/belum memiliki NUPTK/NRG. Sehingga dapat membantu Guru PAI secara adminstratif. Pada bagian ini pula dalam rangka memperkenalkan pola baru tentang pengusukan angka kredit bagi kenaikan pangkat dan jabatan Guru PAI, maka diadakan Sosialisasi Jabatan Fungsional Guru dan Angka Kreditnya.

4) Peningkatan kreasi dan kreatifitas Pendidikan Agama Islam. Rencana program yang diusung meliputi: (1) lomba pentas PAI, (2) lomba Guru PAI berprestasi, (3) lomba KTI/PTK bagi Guru PAI, dan (4) lomba kreatifitas Guru PAI dalam mengembangan

${ }^{14}$ Ibid. h. 39. 
media pembelajaran berbasis IT. Melalui rencana program tersebut diharapkan mampu memberikan wadah kreatifitas dan apresiasi terhadap Guru PAI dalam mengembangkan kompetensi dan profesionalitas mereka sehingga tujuan utama dari pendidikan secara utuh dapat tercapai. ${ }^{15}$

Mengingat pentingnya pendampingan pada implementasi K 2013 bagi para guru dan kepala madrasah, maka badan Pengembangan Sumber Daya Manusia Pendidikan dan Kebudayaan dan Penjaminan Mutu Pendidikan, kementerian Pendidikan dan Kebudayaan menyusun Pedoman Penyelenggaraaan Kegiatan pendampingan implementasi K 2013 untuk menyelaraskan persepsi dan langkah yang telah disepakati bersama dalam menyelenggarakan kegiatan tersebut. Pedoman ini menjadi acuan para pengawas, pra kepala madrasah dan para guru agar pelaksanaan kurikulum sesuai dengam kebijakan yang telah ditetapkan.

Proses pendampingan melalui proses supervisi pada implementasi K 2013 terhadap guru dan kepala madrasah diharapkan mereka dapat menerapkan K 2013 sesuai dengan konsep pengelolaan pembelajaran yang diamanatkan sesuai pada jenjang dan satuan pendidikan, meliputi:

1) Kurikulum 2013 tersosialisasikan kepada seluruh warga madrasah, mulai dari rasional, elemen perubahan kurikulum berdasarkan SKL, Kl dan KD dengan berbagai pendekatan sampai dengan stategi implementasi kurikulum 2013.

2) Kurikulum 2013 diimplementasikan sesuai kaidah, makna dan prosedur yang tercakup dalam elemen perubahan kurikulum berdasarkan SKL, KL dan KD.

3) Rencana Pelajaran Pembelajaran (RPP) disusun berdasarkan karakteristk dan tuntutan kurikulum 2013.

4) Pembelajaran dilaksanakan dengan pendekatan dan strategi penilaian yang tercantum dalam penerapan kurikulum 2013.

5) Penerapan pendekatan dan strategi penilaian yang tercantum dalam penerapan kurikulum 2013.

6) Laporan hasil implementasi kurikulum 2013 disusun berdasarkan format dan otline yang dipersayaratkan. ${ }^{16}$

Kegiatan pendampingan implementasi kurikulum 2013 difokuskan pada fasilitasi penerapan K 2013 oleh guru dan kepala madrasah di satuan pendidikannya, yaitu di kelas 1 dan kelas IV MIN, kelas VII MTSN, dan kelas X MA. Materi pendampingan yang dilakukan oleh pengawas madrasah, kepala madrasah dan guru inti terhadap guru mencakup implementasi konsep K 2013, analisis materi ajar, merancang model dan evaluasi pembelajaran. Sedangkan pendampingan pengawas Madrasah terhadap kepala Madrasah difokuskan pada pengelolaan kurikulum 2013, termasuk di dalamnya implementasi pembelajaran tematik terpadu di MIN dan MTSN (untuk IPA dan IPS), dan mata pelajaran serta peminatan peserta didik di MA. Kegiatan pendampingan persiapan diarahkan dalam upaya menjamin terselenggaranya kegiatan pembelajaran yang memperkuat pendekatan ilmiah (scientific), tematik terpadu (tematik antar matapelajaran) perlu diterapkan pembelajaran berbasis penyingkapan/penelitian (discovery/inquiry learning. Demikian pula

${ }^{15}$ Ibid. h. $42 .$.

${ }^{16}$ Ibid 
dengan pendekatan pembelajaran yang menghasilkan karya berbasis pemecahan masalah (project based learning) untuk mendorong kemampuan peserta didik menghasilkan karya kontekstual, baik individual maupun kelompok.

Secara rinci materi-materi tersebut adalah sebagai berikut:

1) Penguasaan konsep pembelajaran yang sesuai dengan $K 2013$ yang mencakup dan diskus tentang alas an yang dikembangkan dan diberlakukan K 2013 serta elemen perubahan kurikulum berdasarkan SKL, KI dan KD.

2) Penyusunan Rencana Pelaksanaan Pembelajaran (RPP) sesuai dengan silabus dan pendekatan serta strategi pembelajaran di masing-masing jenis dan jenjang pendidikan.

3) Pelaksanaan pembelajaran sesuai karakteristik jenis dan jenjang pendidikan, seperti pendekatan tematik terpadu di madrasah, di samping itu, fasiltasi kegiatan pembelajaran juga difokuskan pada terwujudnya pendekatan santifik, discovery learning, project based, inquiry learning, dan high oeder thingking skills dalam pembelajaran.

4) Pelaksanaan penilaian sesuai dengan kebutuhan dan kaidah-kaidah penilaian authentic assessment, penggunaan penilaian acuan kriteria dan portofolia.

5) Pengelolaan kurikulum bagi kepala Madrasah dan pengawas Madrasah mencakup fasilitasi perubahan mindset berkenaan dengan keterbukaan, keyakinan, dan penerimaan terhadap kurikukulum 2013, program membangun budaya Madrasah, penyusunan RKS, pelaksanaan pengelolaan kurikulum 2013, termasuk pengelolaan pembelajaran tematik terpadu di MI dan MTs, serta pengelolaan mata pelajaran dan program peminatan peserta didik di MA, fasilitasi untuk mewujudkan kepemimpinan pembelajaran dalam pelaksanaan supervisi akademik, evaluasi program, pelaksanaan penataan dokumen/administrasi Madrasah yang mendukung keterlaksanaan kurikulum 2013. Di samping materi pendampingan di atas, pelaksanaan juga diarahkan pada upaya menghimpun berbagai kendala dan alternative pemecahan masalah implementasi kurikulum di masing-masing satuan pendidikan. ${ }^{17}$

Adapun bentuk pengajaran terpadu dalam bidang pendekatan pembelajaran yaitu berdasarkan PP 19/2005 mengamanatkan bahwa pendekatan pembelajaran dengan pendekatan tematik/terpadu dilandasi oleh keunggulan: 1). Sesuai dengan perkembangan peserta didik (Developmentally Appropriate Practice; 2). Sesuai dengan pola berpikir anak (Holistic; 3).Sesuai dengan prinsip ketuntasan belajar (mastery learning); 4). Sesuai dengan prinsip kebermaknaan dalam belajar (meaning full); 5). Sesuai dengan karakteristik anak yang ingin mendapatkan kegembiraan dalam belajar (joyfull learning); 6). Mampu memancing siswa aktif dalam belajar (student active learning); 7). Menerapkan pendekatan kontekstual dalam belajar (contextual teaching and learning. 18

Menjadi kewajiban para pengawas, para kepala madrasah dan guru untuk bersinergi dalam penciptaan belajar siswa dengan pengajaran dengan pendekatan pembelajaran dengan pendekatan tematik/terpadu dilandasi oleh keunggulan-keunggulan yang telah ditetapkan. Secara rinci Pengawas Pendidikan Agama Islam pada Sekolah / madrasah sebagaimana dimaksud KMA No. 2 Tahun 2012 dalam pasal 2 ayat (2) berwenang:

${ }^{17}$ Ibid, h. 28-29.

${ }^{18}$ Departemen Pendidikan Nasional, Loc Cit, h. 3. 
a) Memberikan masukan, saran, dan bimbingan dalam penyusunan, pelaksanaan, dan evaluasi pendidikan dan/atau pembelajaran pendidikan agama Islam kepada kepala sekolah dan instansi yang membidangi pendidikan agama Islam di Kabupaten/kota;

b) Memantau dan menilai kinerja guru PAI serta merumuskan saran tindak lanjut yang diperlukan;

c) Melakukan pembinaan terhadap guru PAI;

d) Memberikan pertimbangan dalam penilaian pada pelaksanaan tugas guru PAI kepada pejabat yang berwenang; dan

e) Memberikan pertimbangan dalam penilaian pelaksanaan tugas dan penempatan guru PAI dan kepala sekolah dan pada pejabat yang berwenang.

f) Menanda tangani/mengesahkan perangkat pembelajaran guru PAI. 19

Wewenang pengawas yang begitu besar hendaknya menjadi pendorong bagi pengawas untuk meningkatkan wawasan dan kemampuan profesional, serta dapat bersinergi dengan para kepala madrasah dan para guru sehingga proses implementasi kurikulum yang telah ditetapkan berjalan dengan baik.

\section{b. Supervisi Akademik Implementasi Kurikulum 2013.}

Kurikulum 2013 telah memuat beberapa perubahan, khususnya Mata Pelajaran PAI dan pembelajarannya: (a) adanya pertambahan jam pelajaran bagi Pendidikan Agama Islam (PAI). Jika pada Kurikulum 2006, PAI hanya 2 jam per minggu maka pada Kurikulum 2013 mengalami pertambahan 3 jam per minggu.

Meskipun pertambahan itu juga sebagai akibat adanya transformasi dari istilah mata pelajaran yang semula hanya PAI, sekarang menjadi PAI dan Budi Pekerti. (b) reorientasi pendekatan pembelajaran PAI. Kurikulum 2013 memperkenalkan pendekatan baru dalam proses pembelajaran PAI yaitu dengan memperkenalkan "pendekatan sainstifik (baca: scientific), yang pada pembelajaran sains lebih dikenal dengan istilah pendekatan keterampilan proses sains". 20

Lebih lanjut dijelaskan bahwa ${ }^{21}$ pada konteks ini seorang pengawas PAI bertugas melakukan supervisi kepada para guru dalam mengaplikasikan pendekatan sainstifik dengan melakukan beberapa langkah dalam membelajarkan peserta didik, yaitu:

1) Siswa harus dihadapkan pada fenomena konkret baik fenomena alam, sosial, maupun budaya dengan harapkan mereka benar-benar dihadapkan pada kondisi nyata dan otentik.

2) Dari fenomena tersebut akan tumbuh inkuiri siswa dengan melakukan pertanyaan apa, mengapa dan bagaimana hal itu bisa terjadi. Inilah langkah kedua.

3) Untuk memperoleh jawab pertanyaan tersebut peserta didik difasilitasi untuk menggali, mengkaji, memahami permasalahan melalui serangkaian kegiatan seperti mengeksplor perpustakaan (study library), mencari nara sumber langsung (study lapangan) ataupun melakukan percobaan (study experiment) yang pada intinya mereka memperoleh jawab dari pertanyaan mereka.

\footnotetext{
${ }^{19}$ Keputusan Menteri Agama No. 2 Tahun 2012 dalam pasal 2 ayat (2).

${ }^{20}$ Ibid. h. 39.

${ }^{21}$ Ibid. h. 39..
} 
4) Yang merupakan langkah terakhir setelah mendapatkan data yang valid dari berbagai sumber, maka peserta didik harus mampu mengkomunikasikan hasil mereka dalam forum diskusi kelas untuk mendapatkan penguatan baik dari peserta didik lain maupun guru PAI.

Secara umum, pengawas PAI harus dapat melakukan proses supervisi pada implementasi kurikulum 2013. Hal ini menuntut setiap pengawas madrasah memiliki kompetensi yang baik di bidang supervisi akademik. Kompetensi supervisi akademik adalah "merupakan salah satu kompetensi yang harus dimiliki oleh para pengawas satuan pendidikan". ${ }^{22}$

Kompetensi ini berkenaan dengan kemampuan pengawas dalam rangka pembinaan dan pengembangan kemampuan guru untuk meningkatkan mutu pembelajaran dan bimbingan di sekolah/satuan pendidikan. Pada konteks implementasi K 2013, maka setiap pengawas pada satuan pendidikan harus memiliki kemampuan untuk membantu guru dalam mengembangkan strategi pembelajaran, serta dapat memilih strategi yang tepat dalam kegiatan pembelajaran sesuai dengan tuntutan K 2013. Melalui proses sosialisasi, supervisi administrasi, supervisi akademik dan supervise klinis pengawas PAI dapat membantu para kepala madrasah dan para guru untuk melaksanakan tugasnya dalam implementasi kurikulum 2013 secara baik.

Lebih spesifik lagi bagi pengawas PAI bertugas mendorong guru untuk memperhatikan empat kompetensi guru yang relevan bagi kesuksesan implementasi K 2013, yaitu: ${ }^{23}$

1) Kompetensi Guru PAI dalam pemahaman substansi bahan ajar, yaitu terkait dengan metodologi pembelajaran.

2) Kompetensi akademik, karena Guru PAI sesungguhnya memiliki tugas untuk bisa mencerdaskan peserta didik, jika Guru PAI hanya menguasai metode penyampaiannya tanpa kemampuan akademik, maka peserta didik tidak akan mendapatkan ilmu pengetahuan.

3) Kompetensi sosial. Guru PAI harus juga bisa dipastikan memiliki kompetensi sosial, karena ia tidak hanya dituntut cerdas dan bisa menyampaikan materi keilmuannya dengan baik, tapi juga dituntut untuk secara sosial memiliki komptensi yang memadai.

4) Kompetensi manajerial atau kepemimpinan. Ini adalah jauh lebih penting, karena pada konteks ini Guru PAI tidak sekedar mencerdaskan peserta didik dalam makna intelektual (IQ), tetapi juga mencerdaskan dalam makna emosi (EQ) dan spiritualnya (SQ).

Secara spesifik deskripsi tugas pengawas PAI dalam program pendampingan dan supervisi implementasi K 2013 yaitu:

1). Melakukan supervisi dan fasilitasi keterlaksanaan pengelolaan K 2013 yang dilakukan kepala madrasah yang meliputi:

a) Perubahan mindset berkenaan dengan keterbukaan keyakinan dan penerimaan terhadap K 2013

22 Departemen Pendidikan Nasional, Strategi Pembelajaran dan Pemilihannya, (Jakarta: Direktorat Tenaga Kependidikan Direktorat Jenderal Peningkatan Mutu Pendidik dan Tenaga Kependidikan, 2008), h. 3

${ }^{23}$ Ibid. h. 39.. 
b) Program membangun budaya madrasah untuk tercapainya standar kompetensi lulusan pada K 2013.

c) Menyusun rencana kerja madrasah sesuai dengan prinsip-prinsip manajemen perubahan dalam pelaksanaan K 2013.

d) Melaksanakan pengelolaan K 2013 sesuai dengan RKS yang disusun

e) Mewujudkan kepemimpinan pembelajaran dalam pelaksanaan supervisi akademik sesuai K 2013

f) Melaksanakan evaluasi program pelaksanaan K 2013

g) Melaksanakan penataan dokumen /administrasi madrasah yang mendukung keterlaksanaan kurikulum 2013, program pembelajaran tematik terpadu bagi kepala Madrasah Ibtidaiyah (MI) dan Madrasah Tsanawiyah (MTs) dan peminatan peserta didik pada jenjang Madrasah Aliyah (MA).

2). Melakukan supervisi dan fasilitasi keterlaksanaan perencanaan model pembelajaran yang meliputi:

a) Perubahan mindset keterbukaan keyakinan dan penerimaan terhadap kurikulum 2013.

b) Rencana pelaksanaan pembelajaran

c) Pelaksanaan pembelajaran dengan penerapan saintific discovery learning dan project based learning.

d) Pelaksanaan penilaian otentik. ${ }^{24}$

Pelaksanaan implementasi K 2013 akan bersinergi dengan upaya madrasah dalam menciptakan budaya mutu di madrasah. Menjadi salah satu tugas bagi pengawas madrasah memiliki tugas untuk mendorong penciptaan budaya mutu sekolah.

Terdapat 5 hal perwujudan dari budaya mutu sekolah yaitu:

1) Struktur, yaitu susunan kepengurusan sekolah (madrasah) yang diproporsikan sesuai dengan disiplin keilmuannya.

2) Fokus, bahwa keberadaan organisasi tersebut telah diakui secara tegas baik secara hukum ataupun memiliki nilai plus di mata masyarakat.

3) Komunikasi, yaitu sebuah interaksi harmonis yang dilakukan baik secara internal organisasi (setiap orang yang terlibat dalam organisasi ataupun eksternal (masyarakat sebagai konsumsi).

4) Gaya (style), yaitu sebuah organisasi yang berjalan di atas nilai-nilai dan tidak bersifat pragmatis. Sekolah yang menjalankan pendidikan di tingkatan praktis haruslah mengindahkan nilai-nilai yang berlaku di lingkungan sosialnya, kemudian menjadikannya rujukan dalam menformulasikan draf kerja yaitu kurikulum yang menpresentasikan kepentingan semua pihak (steak holder).

5) Responsif, artinya keterbukaan dalam menerima berbagai saran atau kritik yang konstruktif. ${ }^{25}$

Dalam perkembangannya, budaya budaya mutu di madrasah akan di pengaruhi oleh isu-isu kekinian yaitu:

\footnotetext{
${ }^{24}$ Sukron, Op Cit, h. 29.

${ }^{25}$ Johns West dan Burham, Managing Quality in School, (London: Prentice Hel, 1988), h. 99.
} 
1) Nilai-nilai dan tugas, yang termasuk di dalamnya masyarakat (publik), unsur-unsur yang terdapat dalam lingkungan sosial, mengerti akan hal yang diperbuat.

2) Struktur organisasi, bahwa struktur organisasi tersusun secara herarki dengan berbagai macam komponen dan dapat dipertanggung jawabkan keberadaannya,

3) Komunikasi, interaksi harmonis yang harus diciptakan di antara kelompok-kelompok kerja atau unsur antar individu dalam sharing informasi yang berkualitas,

4) Pengambilan keputusan yang didasari mupakat, dalam artian bahwa keputusan tersebut merupakan representasi dari aspirasi semua pihak dalam rangka peningkatan kualitas,

5) Tempat kerja haruslah nyaman dan dapat memberi suasana fresh yang tentunya diharapkan dapat menimbulkan gairah kerja yang optimal,

6) Rekrutmen dan seleksi, yaitu memilih dan memilah secara slektif dalam menempatkan setiap individu dalam menangani bidang kerja yang telah diatur (job discription),

7) Perencanaan kurikulum yang dinamis, mudah dipahami dan fleksibel,

8) Pengelolaan pendanaan dan sumber dana secara profesional dan tepat guna,

9) Perhatikan terhadap kesejahteraan dan kedisiplinan secara efektif dalam berbagai hal yang terkait,

10) Komunitas, yakni hubungan berkualitas yang dibangun atas dasar kerjasama yang harmonis dan secara kebersamaan terhadap semua relasi kerja internal dan eksternal. ${ }^{26}$

Pada proses penciptaan budaya mutu sekolah (madrasah) yang berkualitas, Total quality hanyalah sebuah sarana, artinya harus dapat diaplikasikan dalam konteks yang spesifik dan riil pada pengembangan mutu di lembaga pendidikan.Pada aktualisasi budaya mutu di madrasah yang baik inilah akan memungkinkan tingkat keberhasilan implementasi K 2013 secara maksimal dan bersinerginya semua stakeholder penjaminan mutu di madrasah.

\section{HASIL PENELITIAN DAN PEMBAHASAN}

\section{Penjaminan Mutu Pendidikan dalam Implementasi Kurikulum K13 melalui Pengawasan Akademik}

Penjaminan mutu pendidikan dalam implementasi K 2013 pada MA di Kota Metro dikoordinir oleh Pengawas PA; Drs. Helmi Efendi, M.Pd, berkoordinasi dengan para kepala MA di Kota Metro, yaitu: Antoni Iswantoro, M. Ed ( Ka. MAN Metro 1; Drs. H. Sutrisno, M. Pdi (Ka. MA Darul Akmal); Ahmad Kholil, S. Hi (Ka. MA Muhammadiyah); Eko Yulianto, S.Pdi (Ka. MA Al Muhsin); Fajri, S.Pdi (Ka. MA Tuma'ninah Yasin); Nurlaela, SE (Ka. MA Khusnul Khotimah); Marlindra, S.Pdi (Ka. MA. Roudhotut Tholibin); dan Neli Ritawati, S.Pd (Ka. MA Mambaul Ulum).

Berdasarkan kondisi kualifikasi Kepala MA di Kota Metro menunjukkan masih diperlukannya motivasi kepada mereka untuk meningkatkan kompetensi akademiknya, yaitu peningkatan kualifikasi pendidikan, karena dari kedelapan kepala MA tersebut hanya dua kepala MA yang berkualifikasi pendidikan S2, dan selainnya masih level S1. Masih terdapat pula dua Kepala MA yang memiliki kualifikasi pendidikan yang tidak linier dengan kependidikan, yaitu satu dengan lulusan Sarjana Ekonomi dan satu lulusan Sarjana Hukum Islam. Idealnya para kepala MA memiliki kualifikasi sarja pendidikan, sehingga lebih

${ }^{26}$ Ibid, h. 100-101. 
memahami dan mampu melaksanakan kepemimpinan di lembaga pendidikan pada level MA dengan lebih baik.

Demikian pula diperlukannya motivasi yang kuat dari masing-masing kepala MA yang memiliki kualifikasi pendidikan yang masih pada level S1 Pendidikan/Tarbiyah untuk dapat melanjutkan pada jenjang pendidikan yang lebih tinggi, mengingat statusnya sebagai model (uswatun hasanah) dari para pendidik dan tenaga kependidikan pada masing-masing MA, dan diantara mereka para pendidik dan tenaga kependidikan sudah banyak yang memiliki kualifikasi S2. Pada sisi lain, Pengawas PAI dan Para Kepala MA di Kota Metro harus bersinergi pula dengan seluruh para pendidik dan tenaga kependidikan MA yang ada di Kota Metro. Spesifikasi pada peningkatan mutu pendidikan terkait implementasi kurikulum 2013 pada rumpun mata pelajaran PAI di level MA, maka kondisi dan segala hal terkait para guru PAI menjadi hal yang esensi untuk diperhatikan, ditingkatkan secara maksimal sehingga dapat benar-benar secara maksimal bersinergi dengan pengawas PAI, para kepala madrasah dalam implementasi Kurikulum 2013 di MA masing-masing.

Pada konteks ini terdapat 55 Guru PAI (Rumpun mata pelajaran Agama Islam di MA yaitu Al Quran Hadist, Aqidah Akhlak, Sejarah Kebudayan Islam, Fiqih dan juga Bahasa Arab). Secara umum para guru tersebut telah memiliki kualifikasi pendidikan S1 Tarbiyah dan mengajar mata pelajaran sesuiai dengan kualifikasi pendidikannya. Terdapat beberapa guru PAI MA yang telah meningkatkan level kualifikasi pendidikan yang dipersyaratkan sebagai guru, yaitu dengan berijazah S2. Terdapat 17 guru PAI berpendidikan S2 Pendidikan/Tarbiyah dan 1 S2 Manajemen. Ketujuh belas guru PAI tersebut idealnya berkonstribusi positif dalam peningkatan mutu pembelajaran pada masing-masing mata pelajaran yang mereka ampu, serta secara umum memberikan konstribusi positif dalam peningkatan mutu dan akreditasi MA yang memerlukan tingkat lulusan pendidik dengan kualifikasi lebih tinggi.

Namun demikian, masih terdapat beberapa guru PAI di MA Kota Metro yang memiliki kualifikasi pendidikan yang tidak linier dengan Kependidikan/Tarbiyah, yaitu 1 sarjana LC, 1 sarjana S.Esy, 1 sarjana S.Sos, 1 sarjana S.Hi dan 1 alumni Ponpes dan 1 alumni SLTA. Berdasarkan kondisi ini, maka diharapkan masing-masing Kepala MA beserta stakeholder yang ada untuk lebih mempertimbangkan aspek profesionalisme, linearitas serta penguatan mutu akademik serta akreditasi MA dalam pengangkatan dan pembinaan tenaga pendidik dan tenaga kependidikan pada masing-masing MA.

Terkait dengan tiga pilar penjamin mutu dalam implementasi Kurikulum 2013 pada MA di Kota Metro, maka ada beberapa hal yang mutlak dipahami dan dilaksanakan oleh semua pihak sehingga sinergitas tiga penjamin mutu pendidikan di MA yaitu Pengawas PAI, Kepala MA dan pendidik dan tenaga pendidikan di masing-masing MA.

a. Kualifikasi Pengawas PAI di MA

Peraturan Menteri Pendidikan Nasional Nomor 12 tahun 2007 tentang Standar Pengawas Madrasah berisi standar kualifikasi dan kompetensi pengawas madrasah. Standar kualifikasi tersebut menjelaskan bahwa persyaratan akademik dan non akademik untuk diangkat menjadi pengawas madrasah. Standar kompetensi memuat seperangkat kemampuan yang harus dimiliki dan dikuasai oleh pengawas madrasah untuk dapat melaksanakan ugas pokok, fungsi dan tanggung jawabnya. 
Terdapat 5 (lima) kompetensi yang harus dimiliki oleh pengawas PAI pada madrasah pada KMA No 2 Tahun 2012 Pasal 8 yaitu: (1). Kompetensi Kepribadian, (2). Kompetensi Supervisi Akademik, (3). Kompetensi evaluasi Pendidikan, (4). Kompetensi Penelitian dan Pengembagan, dan (5). Kompetensi Sosial. Berdasarkan hasil uji kompetensi di beberapa daerah menunjukkan bahwa kompetensi pengawas madrasah perlu lebih ditingkatkan terutama pada dimensi kompetensi supervisi managerial, supervisi akademik, evaluasi pendidikan dan kompetensi penelitian dan pengembangan.

b. Delapan Standar Mutu Pendidikan

Masalah pokok pendidikan Indonesia dewasa ini adalah peningkatan mutu pada setiap jenis, jenjang dan jalur pendidikan. Oleh sebab itu, pemerintah RI telah menetapkan delapan standar nasional (PP No 32 Tahun 2013) yaitu; 1). Standar isi (Permendikbud No 57, 58, 59, 60 Tahun 2014); 2). Standar Proses (Permendikbud No 65 Tahun 2013); 3). Standar Kompetensi Lulusan (Permendikbud No 54 Tahun 2013); 4). Standar Pendidik dan Tenaga Kependidikan (Permendiknas No 16 Tahun 2007); 5). Standar Sarana dan Prasarana (Permendiknas No 24 Tahun 2007); 6). Standar Pengelolaan (Permendiknas No 19 Tahun 2007); 7. Standar Pembiayaan (Permendiknas No 69 Tahun 2007); 8). Standar Penilaian Pendidikan (Permendikbud No 66 Tahun 2015).

Standar pendidikan di atas pada hakekatnya menjadi arah dan tujuan penyelenggaraan pendidikan. Dengan kata lain standar nasional pendidikan harus menjadi acuan sekaligus kriteria dalam menetapkan keberhasilan penyelenggaraan pendidikan. Salah satu standar yang dinilai langsung berkaitan dengan peningkatan mutu pendidikan dan relevan dengan suksesi implementasi kurikulum 2013 pada setiap madrasah adalah adanya program pengawasan dan pembinaan terhadap kinerja tenaga pendidik dan manager satuan pendidikan.

c. Tugas dan Funsi Pokok Pengawas PAI dan Madrasah

Pengawas PAI pada Kantor Kementerian Agama Kota Metro Lampung, sesuai dengan tugas pokok dan fungsinya meruapakn tenaga kependidikan yang peranannya sangat penting dalam membina kemampuan profesional tenaga pendidik dan kepala madrasah dalam meningkatkan kinerja madrasah.

Pengawas madrasah harus dipahami memiliki peranan strategis dalam peningkatan mutu madrasah. Pengawas madrasah dan PAI berfungsi sebagai supervisi akademik. Pengawas madrasah dan PAI bertugas membantu kemampuan professional guru PAI agar para guru tersebut dapat mampu meningkatkan mutu proses pembelajaran. Sedangkan sebagai supervisor manajerial, pengawas PAI berkewajiban membantu kepala madrasah agar mencapai madrasah yang efektif.

d. Pengelolaan Madrasah Efektif oleh Kepala MA

Madrasah Aliyah yang dikelola secara baik dan dapat berjalan efektif ketika MA tersebut dapat diidentifikasikan ke dalam 5 hal yang sangat signifikan yaitu: 1). Pengelolaan manajemen pengajaran dengan baik, 2). Metode dan perilaku mengajar yang menyenangkan; 3). Penerapan kurikulum pengajaran yang tepat; 4). Perilaku kepala madrasah yang mendukung; 5). Sikap guru yang mendukung penuh program madrasah,

Pembinaan dan pengawasan terhadap peningkatan mutu madrasah hendaknya menjadi tugas pokok pengawas madrasah. Oleh karena program pengawasan yang dirancang 
sebagai terjemahan dari tugas pokok dan fungsi pokok dan fungsi pengawas PAI pada madrasah akan menjadi action plan untuk masa satu tahun menjadi sangat penting dilakukan sekaligus menjadi acuan dan barometer kinerja pengawas itu sendiri pada madrasah binaanya.

e. Visi, Misi dan Strategi Pengawasan PAI dan madrasah

Visi kepengawasan PAI di Kota Metro ditetapkan yaitu “Menjadi Pengawas madrasah yang berakhlak mulia, professional, terampil dan populis dalam melaksanakan tugas pokok dan fungsinya di madrasah dalam binaannya".

Misi kepengawasan PAI di Kota Metro ditetapkan yaitu:

1) Membantu kepala madrasah dalam menyusun dokumen KTSP dan Kurikulum 2013 dan guru PAI dalam membuat perangkat pembelajaran secara lengkap,

2) Menciptakan suasana belajar yang menyenangkan dan kreatif dengan membimbing guru di madrasah/sekolah untuk menggunakan pendekatan scientific dalam proses pembelajaran yang terencana, terprogram dan terukur sesuai kemampuan para siswasiswi di madrasah/sekolah binaannya,

3) Membimbing para guru dalam mewujudkan Standar Kompetensi Lulusan (SKL) madrasah/sekolah agar sesuai dengan visi kelulusan peserta didik dari satuan pendidikan madrasah/sekolah binaanya,

4) Membantu para kepala madrasah dan para guru PAI dalam mengelola dan memberdayakan sarana dan prasarana madrasah/sekolah agar berfungsi secara tepat guna,

5) Membantu meningkatkan kompetensi tenaga pendidik dan kependidikan di madrasah/sekolah melalui pelatihan-pelatihan akademis dan bimbingan teknis kependidikan,

6) Memberikan advis dan saran-saran kepada para kepala madrasah dalam mengelola satuan pendidikan agar menerapkan Manajemen Berbasis Madrasah (MBM) yang mandiri, kemitraan, partisipasi, keterbukaan dan akuntabilitas,

7) Membimbing para kepala madrasah, staff dan bendahara dalam mengelola keuangan madrasah agar lebih efektif dalam membelanjakannya sesuai dengan keperluannya,

8) Membimbing dan mengevaluasi guru madrasah/sekolah dalam memberikan penilaian hasil belajar siswa, agar menggunakan penilaian auttentik dalam hasil beajar siswa,

f. Srategi Pengawasan

Program kerja kepangawasan dilaksanakan dengan melihat hasil analisis dan evaluasi kegiatan yang telah dilaksanakan pada tahun-tahun sebelumnya dan merujuk pula pada program kerja Pokjawas Kantor Kementerian Agama Kota Metro Lampung dengan strategi kegiatan sebagai berikut:

(1) Identifikasi masalah dan hasil kepengawasan tahun sebelumnya,

(2) Pembahasan hasil dari fakta dan data madrasah/sekolah binaan masing-masing pengawas dari aspek akademik dan manajerial,

(3) Pengelolaan dan analisis data dan fakta kondisi riil madrasah binaan,

(4) Rancangan program pembinaan dan tindak lajut hasil pembinaan, 
(5) Pemantapan program dan rekomendasi kebijakan pengelolaan pendidikan stakeholder bagi peningkatan mutu madrasah/sekolah.

g. Ruang Lingkup Pengawasan

Standar Nasional Pendidikan pasal 19 disebutkan bahwa proses pembelajaran pada satuan pendidikan diselenggarakan secara interaktif, inspiratif, menyenangkan, menantang, memotivasi peserta didik untuk berpartisipasi aktif, serta memberikan ruang yang cukup bagi prakarsa, kreativitas, dan kemandirian sesuai dengan bakat, minat, dan perkembangan fisik serta psikologi peserta didik.

Pengawasan proses pembelajaran sebagaimana dimaksud dalam pasal 19 ayat 1 di atas meliputi pemantauan, supervisi evaluasi, pelaporan dan pengambilan langkah tindak lanjut yang diperlukan. Hal ini berarti pelaksanaan pengawasan pendidikan di tingkat satuan pendidikan memiliki ruang lingkup: pemantauan, supervisi, evaluasi, pelaporan dan pengambilan langkah tindak lanjut.

Pemantauan merupakan pengawasan yang dilaksanakan langsung terhadap proses pembelajaran yang dilakukan para guru di madrasah. Hal ini dilakukan untuk melihat secara riil pelaksanaan proses pendidikan secara komprehensif dan faktual. Supervisi dilakukan untuk mengembangkan dan meningkatkan situasi dan proses pembelajaran menjadi lebih baik dan berkualitas, sedangkan evaluasi dimaksudkan sebagai proses penilaian trhadap proses pembelajaran yang dilaksanakan, terkait kesesuaian dengan stndar penilaian kompetensi yang menjadi target dalam perencanaan pembelajaran. Kemudian pelaporan merupakan data tertulis yang diperoleh dari hasil pemantauan, supervisi. Data tersebut sekaligus menjadi acuan untuk perbaikan dan peningkatan proses pendidikan yang dilaksanakan di madrasah. Terakhir adalah tindak lanjut yang merupakan lingkup terakhir dalam pengawasan yang lebih diarahkan kepada pejabat yang memiliki kewenangan untuk mengambil kebijakan.

\section{Problematika Penjaminan Mutu Pendidikan dalam Implementasi Kurikulum K13 melalui Pengawasan Akademik.}

a. Masalah-masalah dalam Pengawasan.

Masalah dalam pengawasan mencakup masalah pembinaan, pemantauan dan masalah penilaian. Dalam naskah akademik tentang standar pengawasan satuan pendidikan yang dikeluarkan oleh badan Standar Nasional Pendidikan (BSNP) dijelaskan bahwa: “Tugas pokok pengawas satuan pendidikan sebai supervisor pendidikan baik bidang akademik maupun bidang manajerial adalah monitotring/pemantauan, penilaian, pembinaan, dan pengembangan serta pelaporan dan tindak lanjut".

Monitoring/pemantauan, penilaian dan pembinaan yang dilakukan dalam pengawasan yang telah dijalankan oleh pengawas bersinergi dengan kepala madrasah dan para guru dapat dilaksankan dengan upaya yang makasimal, namun demikian terdapat beberapa masalah yang ditemukan dalam pengawasan yang dapat disimpulkan sebagai berikut:

1). Masalah dari Sisi Pengawas

(a). Masih kurangnya pendidikan dan pelatihan peningkatan kompetensi dalam perubahan pendidikan yang sedemikian cepat pada akhir-akhir ini, seharusnya pengawas dilatih dan dididik terlbih dahulu agar dapat memberikan pembinaan terhadap satuan pendidikan, 
(b). Keterlambatan informasi yang berkembang di bidang pendidikan, karena dari pihak struktural mendahulukan penyampaian informasi kepada madrasah daripada ke pengawas,

(c). Kurang memadainya sarana dan prasarana serta dana supervisi dalam menjalankan tugas kepengawasan, karena kondisi sekarang kurang memadai,

2). Masalah dari Sisi Madrasah yang Diawasi

(a). Belum tersosialisasikannya Kurikulum 2013 dengan baik dan merata terutama kepada para guru, baik secara dokumen I dana dari maupun dokumen II, demikian juga dalam pendidikan dan pelatihannya. Hal inilah dikarenakan keterbatasan waktu dan dana dari pihak terkait.

(b). Kurangnya kemampuan SDM guru dalam perencanaan, pelaksanaan dan evaluasi, serta tindak lanjut pembelajaran, dikarenakan minimnya pendidikan dan pelatihan.

(c). Belum memadainya sarana dan prasarana madrasah, baik yang terkait dengan akademik maupun managerial,

(d). Kurangnya tenaga pendidik dan kependidikan, baik dari jumlah personal maupun dari kualifikasi dan kompetensinya.

\section{3). Masalah dari Sisi Guru PAI pada Madrasah}

(a). Masih kurang memahami teknik penyusunan silabus dan RPP yang sesuai denga pedomanyang dikeluarkan oleh Depdiknas, hal ini dikarenakan kurangnya pendidikan dan pelatihan,

(b). Belum terlaksanakannya proses pembelajaran sesuai Permendikbud No/65 tahun 2013 tentang Standar Proses, karena pada tahun-tahun belakangan ini kurang mendapatkan pembinaan melalui penataran atau pelatihan,

(c). Masih terdapat kelemahan di dalam pelaksanaan evaluasi pembelajaran dan tindak lanjut sebagaimana yang telah diatur dalam Permendikbud No. 66 Tahun 2013 tentang Standar Penilaian Pendidikan,

(d). Ketika harus memenuhi 24 jam mengajar pada setiap minggunya, terdapat beberapa guru harus mengajar di lebih dari satu tempat sehingga konsekuensinya kurang efektifnya pelaksanaan kegiatan belajar mengajar yang dilaksanakan oleh para guru tersebut.

\section{Pelaksanaan Sinergitas Penjaminan Mutu Pendidikan dalam Implementasi Kurikulum K13 melalui Pengawasan Akademik.}

Ruang lingkup tugas pokok pengawas madrasah satuan pendidikan adalah melakukan penilaian dan pembinaan dengan melaksanakan fungsi-fungsi supevisi, baik supervisi akademik maupun supervisi manajerial. Demikian pula dengan pengawasan pada madrasah dan para guru PAI di Kota Metro.

Tiga pilar penjamin mutu pendidikan MA di Kota Metro yaitu Pengawas PAI, Para Kepala Madrasah dan para guru PAI bersinergi dan berkoordinasi dengan baik untuk mewujudkan tiga kegiatan yang harus dilaksanaan dalam kegiatan pengawasan yaitu: a). Melakukan monitoring terhadap pelaksanaan program madrasah beserta pengembangannnya; b). Melakukan evaluasi dan penilaian terhadap proses dan hasil program pengembangan 
madrasah secara kolaboratif dengan stakeholder madrasah, dan c). Melakukan pembinaan pengembangan kualitas madrasah, kinerja kepala madrasah, guru dan staf madrasah.

Mengacu pada Surat Keterangan Menteri Pemberdayaan Aparatur Negara (Menpan) No 118 Tahun 1996 tentang Jabatan Fungsional Pengawas dan Angka Kreditnya, Keputusan bersama Menteri Pendidikan dan Kebudayaan) Mendikbud Nomor 0342/O/1996 dan Kepala badan Afministrasi Kepegawaian Negara Nomor 38 tahun 1996 tentang petunjuk pelaksanaan jabatan fungsional pengawas madrasah dan angka kreditnya, dapat dikemukakan tentang tugas pokok dan tanggung jawab pengawas Pendidikan Agama Islam adalah menilai dan membina tekhnis pelaksanaan Pendidikan Agama Islammdi madrasah.

Demikian pula dengan pelaksanaan pengawasan PAI di MA Kota Metro, maka Pengawas PAI, Kepala Madrasah dan para guru rumpun PAI di madrasah bersinergi dalam suksesi pada: a). Melaksanakan supervisi/kepengawasan terhadap penyelenggaraan pendidikan dan pengembangan Agama Islam dan penyelenggaraan di madrasah (manajerial); b). Melakukan supervisi/pengawasan terhadap pelaksanaan, tugas guru PAI dan guru pada madrasah, dan c). Melakukan supervisi/pengawasan terhadap pelaksanaan ekstra kurikuler PAI pada tingkatan madrasah yang menjadi tanggung jawabnya.

Tugas pokok yang pertama merujuk pada supervisi atau kepengawasan manajerial sedangkan tugas pokok kedua dan ketiga merujuk pada supervisi atau pengawasan akademik. Pengawasan manajerial pada dasarnya memberikan pembinaan, penilaian dan bantuan/bimbingan mulai dari rencana program, proses, sampai dengan hasil. Bimbingan dan bantuan diberikan kepada para kepala madrasah dan seluruh staf madrasah dalam pengelolaan madrasah atau penyelenggaraan pendidikan dan pengajaran di madrasah untuk meningkatkan kinerja madrasah. Pengawasan akademik berkaitan dengan membina dan membantu guru dalam meningkatkan kualitas pembelajaran/bimbingan dan hasil belajar siswa, dan dalam konteks penelitian ini yaitu suksesi implementasi Kurikulum 2013 pada level Madrasah Aliyah di Kota Metro.

Pengawas madrasah dan PAI bersinergi dengan para kepala madrasah serta para guru dan staf di madrasah binaanya untuk dapat melaksanakan kewenangannya sebagai seorang pengawas MA dan PAI di MA, yaitu meliputi: a). Memilih dan menentukan metode kerja untuk mencapai hasil yang optimal dalam melaksanakan tugas dengan sebaik-baiknya sesuai dengan kode etik profesi sebagai pengawas MA dan PAI di MA; b). Menetapkan tingkat kinerja guru dan tenaga lainnya yang diawasi beserta faktor-faktor yang mempengaruhinya, dan c). Menentukan atau mengusulkan program pembinaan serta melakukan pembinaan.

Kewenangan tersebut mengisyaratkan adanya otonomi pengawas untuk menentukan langkah dan strategi dalam menentukan prosedur kerja kepengwasan. Namun demikian pengawas penting untuk berkolaborasi serta bersinergu dengan para kepala madrasah dan para guru serta staf madrasah agar dalam melaksanakan tugasnya sejalan dengan arah pengembangan madrasah yang telah ditetapkan oleh kepala madrasah masing-masing. Berdasarkan kedua tugas pokok di atas, maka Pengawas MA dan PAI MA Kota Metro melaksanakan kegiatan kepengawasan pendidikan yaitu:

a) Menyusun program kerja kepengawasan untuk setiap semester dan setiap tahunnya pada madrasah yang dibinanya, 
b) Melaksanakan penilaian, pengelolaan dan analisis data hasil belajar/bimbingan siswa dan kemampuan guru,

c) Mengumpulkan dan mengolah data sumber daya pendidikan, proses pembelajaran/bimbingan, lingkungan madrasah yang berpengaruh terhadap perkembangan hasil belajar/bimbingan siswa,

d) Melaksanakan analisis komprehensif hasil analisis berbagai faktor sumber daya pendidikan sebagai bahan untuk melakukan inovasi madrasah,

e) Memberikan arahan, bantuan dan bimbingan kepada guru tentang proses pembelajaran/bimbingan yang bermutu untuk meningkatkan mutu proses dan hasil belajar/bimbingan siswa,

f) Melaksanakan penilaian dan monitoring penyelenggaraan pendidikan di madrasah binaanya mulai dari penerimaan siswa baru, pelaksanaan pembelajaran, pelaksanaan ujian sampai kepada pelepasan lulusan/pemberian ijazah,

g) Menyusun laporan hasil pengawasan di madrasah binaanya dan melaporkannya kepada Kementerian Agama dan stakeholder lainnya,

h) Melaksanakan penilaian hasil pengawasan seluruh madrasah sebagai bahan kajian untuk menetapkan program kepengawasan semester/tahun berikutnya,

i) Memberikan bahan penilaian kepada madrasah dalam rangka akreditasi madrasah,

j) Memberikan saran dan pertimbangan kepada pihak madrasah dalam memecahkan masalah yang dihadapi madrasah berkaitam dengan penyelenggaraan pendidikan.

Berdasarkan wawancara dengan pengawas MA di Kota Metro, secara berkala sebulan sekali atau berdasarkan faktor urgensi atau kebutuhan pembinaan, maka pengawas MA secara maksimal berusaha melaksanakan tugas pengawas yang mencakup: Inspection, Advising, Monitoring, Reporting, Coordinating dan Performing Leadership.

a) Tugas pokok Inspection, meliputi tugas mensupervisi kinerja kepala madrasah, kinerja guru, kinerja staf madrasah, pelaksanaan kurikulum/mata pelajaran, pelaksanaan pembelajaran, ketersediaan dan pemanfaatan sumberdaya, manajemen madrasah, dan aspek lainnya seperti: Keputusan moral, pendidikan moral, kerjasama dengan masyarakat,

b) Tugas pokok Advising, yaitu memberikan advis/nasehat yang meliputi advis mengenai madrasah sebagai sistem, memberikan advis kepada guru tentang pembelajaran yang efektif, memberikan advis kepada tim kerja dan staf madrasah dalam meningkatkan kinerja madrasah, memberikan advis kepada orangtua siswa dan komite madrasah terutama dalam meningkatkan partisipasi masyarakat dalam pendidikan,

c) Tugas pokok monitoring/pemantauan meliputi tugas: memantau penjaminan/standar mutu pendidikan, memantau penerimaan siswa baru, memantau proses dan hasil belajar siswa, memantau pelaksanaan ujian, memantau rapat guru dan staf madrasah, memantau hubungan dengan masyarakat, memantau data statistik kemajuan madrasah, memantau program-program pengembangan madrasah.

d) Tugas pokok Reporting meliputi tugas: melaporkan perkembangan dan hasil pengawasan kepada Kepala Dinas Pendidikan Kabupaten/Kota, Propinsi dan/atau Nasional, melaporkan perkembangan dan hasil pengawasan ke masyarakat public, melaporkan perkembangan dan hasil pengawasan ke madrasah binaannya. 
e) Tugas pokok Coordinating meliputi tugas: mengkoordinir sumber-sumber daya madrasah baik sumber daya manusia, material, financial dll, mengkoordinir kegiatan antar madrasah, mengkoordinir kegiatan preservice dan in service training bagi Kepala Madrasah, guru dan staf madrasah lainnya, mengkoordinir personil stakeholder yang lain, mengkoordinir pelaksanaan kegiatan inovasi madrasah.

f) Tugas pokok Performing Leadership meliputi tugas: memimpin pengembangan kualitas SDM di madrasah binaanya, memimpin pengembangan inovasi madrasah, partisipasi dalam memimpin kegiatan manajeriil pendidikan di Diknas yang bersangkutan, partisipasi pada perencanaan pendidikan di kabupaten/kota, partisipasi pada seleksi calon kepala madrasah, calon pengawas, partisipasi dalam akreditasi madrasah, partisipasi dalam rekrutmen personal untuk proyek atau program-program khusus pengembangan mutu madrasah, partisipasi dalam mengelola konflik di madrasah dengan win win solution dan partisipasi dalam menangani pengaduan baik internal madrasah maupun dari masyarakat. Itu semua dilakukan guna mewujudkan kelima tugas di atas.

Berdasarkan uraian tugas-tugas pengawas MA di atas, maka pengawas PAI pada level MA di Kota Metro berperan besar sebagai: Peneliti, penilai, pengembang, pelopor/inovator, motivator, konsultan, dan kolaborator dalam rangka meningkatkan mutu pendidikan dan pengajaran di MA binaannya. Melengkapi pembahasan di atas, Pengawas MA berkordinasi serta bersinergi dengan para kepala madrasah, para guru serta staf madrasah untuk mencapai tujuan dan sasaran pengawasan madrasah dan PAI di MA secara maksimal. Tujuan pengawasan yaitu: 1). Meningkatkan kompetensi Kepala Madrasah dalam pengelolaan pendidikan, dan 2). Meningkatkan Kemampuan Guru PAI dalam perencanaan, pelaksanaan dan penilaian pembelajaran.

Sedangkan sasaran pengawasan pendidikan yaitu Kepala Madrasah, Tenaga Pendidik dan Kependidikan serta staf pada madrasah, sedangkan pada sekolah umum lebih kepada guru PAI. Uraian dari sasaran pengawasan yang dilakukan oleh Pengawas MA di Kota Metro adalah sebagai berikut: 1). Pelaksanaan kurikulum MA, 2). Kinerja Kepala MA dan stafnya, 3). Kerjasama MA dengan masyarakat, 4). Kepala MA di dalam mengelola pendidikan, 5). Kepala MA dalam melaksanakan inovasi pendidikan, 6). Administrasi MA, 7). Manajemen MA, 8). Pengembangan SDM MA. 9). Penyelenggaraan ujian MA, 10). Penyelenggaraan penerimaan siswa baru MA, dan 11). Mengkordinir kegiatan sumber daya pendidikan.

Kegiatan sumber daya pendidikan yang dikoordinir yaitu: (a). Pelaksanaan kurikulum mata pelajaran, (b). Proses pembelajaran/praktikan/studi lapangan. (c). Kegiatan ekstra kurikuler, (d). Penggunaan media, alat bantu dan sumber belajar; (e). Kemajuan belajar siswa, (F). Pelaksanaan ujian mata pelajaran, (g). Standar mutu hasil belajar siswa; (h). Pengembangan profesi guru, (i). Pengadaan dan pemanfaatan sumber-sumber belajar, (j). Pelaksanaan inovasi pembelajaran, dan (k). Pengadaan sumber-sumber belajar.

Demikian melalui pelaksanaan tugas pokok pengawasan oleh pengawas madrasah dan PAI di Kota Metro dengan bersinergi dengan para kepala madrasah, para guru PAI serta para guru lain dan staf lainnya, peningkatan mutu MA di Kota Metro terus diupayakan termasuk suksesi implementasi kurikulum 2013. Tercapainya tujuan dan sasaran pengawasan MA 
menjadi tanggung jawab bersama dan kekompakan dalam koordinasi serta sinergitas semua pihak menjadi penentu keberhasilan peningkatan mutu MA di setiap aspeknya.

\section{SIMPULAN}

1. Identifikasi hasil kepegawasan dan kebijakan dalam bidang pendidikan dalam kepengawasan PAI level MA di Kota Metro yaitu kegiatan kepengawasan dilaksanakan secara rutin oleh pengawas PAI dan bersifat insidental, baik berupa supervisi akademik, supervisi administrasi dan supervisi klinis.

2. Pola penjaminan mutu pendidikan dalam implementasi Kurikulum K13 melalui pengawasan akademik pada guru rumpun PAI pada MA di Kota Metro dikoordinatori oleh Pengawas PAI dengan memperhatikan aspek kualifikasi Pengawas PAI, Delapan Standar Mutu Pendidikan, Tugas dan Fungsi Pokok Pengawas, Pengelolaan Madrasah Efektif oleh Kepala MA, Visi, Misi dan Strategi Pengawasan PAI, Srategi dan lingkup Pengawasan.

3. Problematika penjaminan mutu pendidikan dalam implementasi Kurikulum K13 melalui pengawasan akademik pada guru rumpun PAI pada Madrasah Aliyah di Kota Metro terdiri atas problema yang terdapat pada pengawas, pada kepala MA dan pada guru PAI. Upaya kreatifits dan kemandirian pada masing-masing personal tersebut, sinergitas dan saling mendukung menjadi sarana efektif dalam mengatasi problema yang ada.

4. Pelaksanaan sinergitas penjaminan mutu pendidikan dalam implementasi Kurikulum K13 dilakukan melalui upaya maksimal pada pengawas PAI, Kepala MA dan para guru rumpun PAI di madrasah dalam suksesi pada: pelaksanaan kepengawasan terhadap penyelenggaraan PAI dan penyelenggaraan tatakelola MA, pelaksanaan pengawasan terhadap pelaksanaan tugas kepala MA dan GPAI MA, dan pengawasan terhadap pelaksanaan ekstra kurikuler PAI pada tingkatan MA yang menjadi tanggung jawabnya. Tugas-tugas tersebut pada operasionalisasinya dirinci dengan berbagai kegiatan pengawasan sebagai perwujudan dari enam cakupan tugas pengawas yaitu Inspection, Advising, Monitoring, Reporting, Coordinating dan Performing Leadership.

\section{DAFTAR PUSTAKA}

Ani Rusilowati, Kurikulum 2013, 87 Persen Guru Kesulitan Cara Penilaian, dalam http:/ / unnes.ac.id/berita/87-persen-guru-kesulitan-soal-penilaian-kurikulum-2013/, diunduh pada tanggal 12 November 2014.

Departemen Pendidikan Nasional, Laporan Hasil Diskusi Kajian Kurikulum Pendidikan Dasar, Jakarta: Badan penelitian dan pengembangan Pusat kurikulum, 2008

Departemen Pendidikan Nasional, Strategi Pembelajaran dan Pemilihannya, Jakarta: Direktorat Tenaga Kependidikan Direktorat Jenderal Peningkatan Mutu Pendidik dan Tenaga Kependidikan, 2008

Departemen Agama RI, Model-Model Pelatihan bagi Pengawas Sekolah, Jakarta: Departemen Agama, 2005. Jenderal Pendidikan Islam Direktorat Pendidikan Agama Islam Kementerian Agama, 2013), h. iii. 
Farida Alawiyah, "Dampak Implementasi Kurikulum 2013 terhadap Guru" dalam INFO SINGKAT (Jakarta: Pengkajian, Pengolahan Data dan Informasi (P3DI) Sekretariat Jenderal DPR RI), Vol. V, No. 19/I/P3DI/Oktober/2013.

Husaini Usman dan Nuryadin Eko Raharjo. "Strategi Kepemimpinan Pembelajaran Menyongsong Implementasi Kurikulum 2013" dalam Cakrawala Pendidikan, Februari 2013, Th. XXXII, No. 1, h. 11-12.

Johns West dan Burham, Managing Quality in School, London: Prentice Hel, 1988.

Pusat Pengembangan Tenaga Kependidikan, Supervisi Akademik Implementasi Kurikulum 2013, Jakarta: Kemendikbud, 2014.

Trianto, "Mempersiapkan Guru PAI dalam Mengimplementasikan Kurikulum 2013", dalam Jurnal Edukasia, MPA 320/Mei 2013, h. 37.

TP.Tiga Masalah Guru dalam Implementasi Kurikulum 2013. Dalam http:/ / news.okezone.com/read/2014/10/16/65/1052959/tiga-masalah-guru-dalamimplementasi-kurikulum-2013, diunduh tanggal, 2 April 2016.

Biodata Penulis: Dr. H. Aguswan Khotibul Umam, Lahir di Cempaka Baru, 1 Agustus 1973, Pendidikan S1 di Fakultas Tarbiyah Metro IAIN Raden Intan 1996, S2 Studi Islam, Psikologi Pendidikan Islam UMY 2004, dan S3 Psikologi UGM 2014. Sekarang Pengampu Mata Kuliah Psikologi Pendidikan di Fakultas Tarbiyah IAIN Metro. 